\begin{tabular}{c} 
Volume and Issues Obtainable at Center for Sustainability Research and Consultancy \\
Journal of Accounting and Finance in Emerging Economies \\
ISSN: 2519-0318 ISSN (E) 2518-8488 \\
Volume 7: Issue 1 March 2021 \\
CSRC \\
Journal homepage: www.publishing.globalcsrc.org/jafee \\
\hline
\end{tabular}

\title{
Disintegrated Market Orientation and Firm Performance: Moderating Effect of Entrepreneurial Orientation
}

\author{
${ }^{1}$ Jawad Hussain, ${ }^{2}$ Palwasha Bibi, ${ }^{3}$ Ashfaq Ahmad, ${ }^{4}$ Hazrat Bilal \\ ${ }^{1}$ Associate Professor, Department of Commerce and Management Sciences, University of Malakand, \\ Pakistan, jawadhussain79@gmail.com \\ ${ }^{2}$ Assistant Professor, Centre for Management and Commerce, University of swat, Pakistan, \\ Dr.palwashabibi@gmail.com \\ ${ }^{3}$ Assistant Professor, Centre for Management and Commerce, University of swat, Pakistan, \\ Ashfaqahmad79@outlook.com \\ ${ }^{4}$ Assistant Professor, Centre for Management and Commerce, University of swat, Pakistan, \\ hbilal@uswat.edu.pk
}

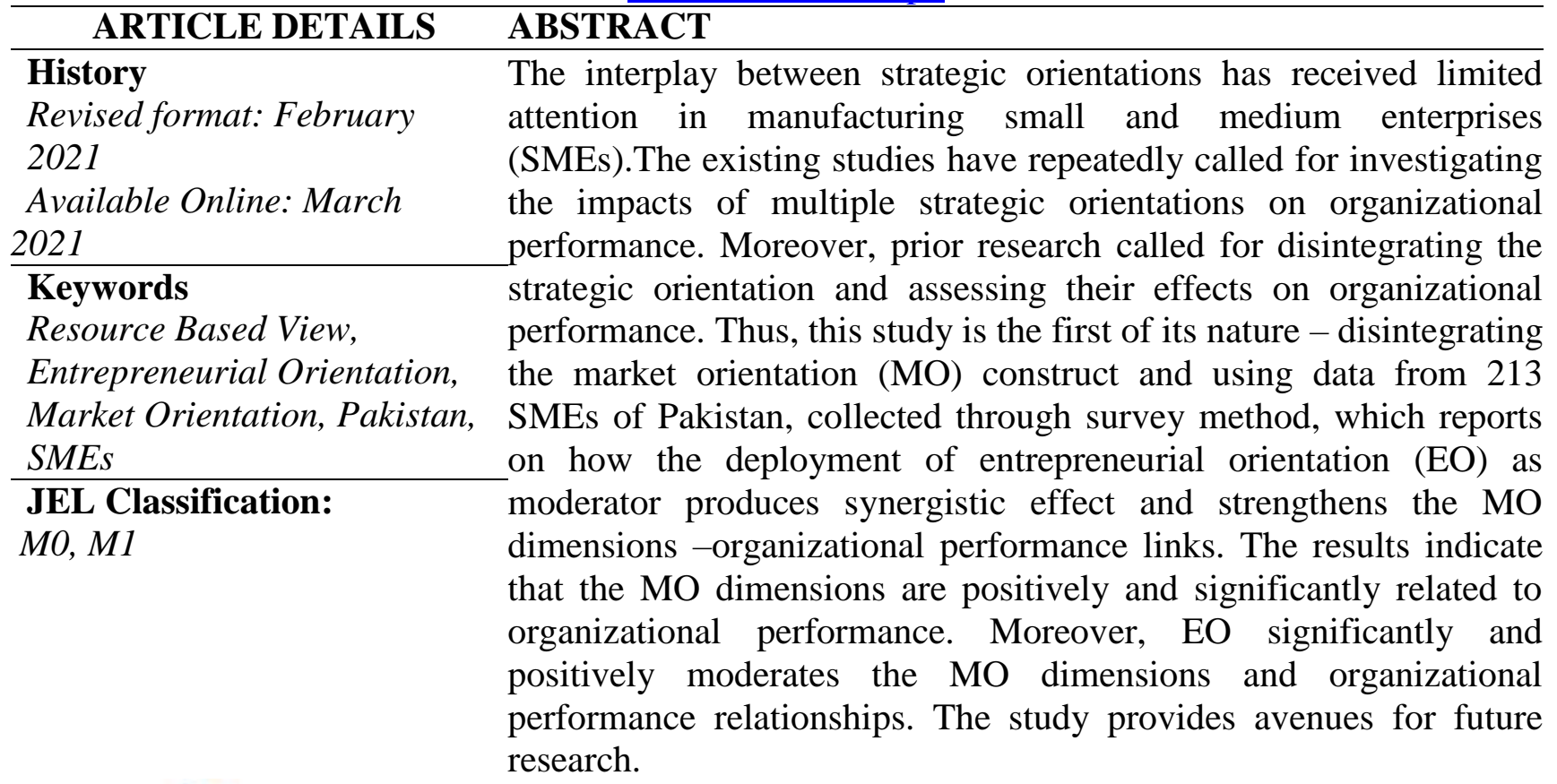

Corresponding author's email address: jawadhussain79@gmail.com

Recommended citation: Hussain, J., Bibi, P., Ahmad, A. \& Bilal, H. (2021). Disintegrated Market Orientation and Firm Performance: Moderating Effect of Entrepreneurial Orientation. Journal of Accounting and Finance in Emerging Economies, 7(1), 155-168

\section{Introduction}

The existing competitive environment demands the business organizations to learn, re-learn and operate prudently in order to compete successfully in the market (Tajeddini, 2011). In this context, those organizations survive and rapidly grow that are capable to effectively deploy their intangible resources (Beliaeva, Shirokova, Wales, \& Gafforova, 2018; Buli, 2017). Prior research has highlighted market 
orientation (MO) as a key intangible resource and organizational capability that enables organizations to adapt to the external environment, exploit emerging opportunities, observe customer needs and anticipate competitor actions (Theodoridis \& Panigyrakis, 2011). MO, by generating and giving best value to clients, facilitates firms to achieve competitive advantage and improved organizational performance (Beneke, Blampied, Dewar, Soriano, \& Deacon, 2016; Yadav, Tripathi, \& Goel, 2019). Research scholars view it as market sensing and customer linking strategy (Kirca, Jayachandran, \& Bearden, 2005) that helps small businesses to be more market oriented that effectively cater to customers' needs (Alnawas \& Hemsley-Brown, 2019).

Although, the prior research has debated the MO-Performance link extensively, the results of the existing studies are conflicting and contradictory (Alnawas \& Hemsley-Brown, 2019; Qu, 2014). Some studies have reported positive relationship (Laukkanen, Nagy, Hirvonen, Reijonen, \& Pasanen, 2013; Shah, El-Gohary, \& Hussain, 2015), while others have reported an insignificant relationship between MO and performance (Baker \& Sinkula, 1999; Grewal \& Tansuhaj, 2001).As a result, the research scholars have not developed a unanimous consensus, and the debate is still ongoing.

Despite the critical role of MO in achieving competitive advantage and improved organizational performance, research scholars argue that firms focusing on implementing a single orientation may not sustain their performance for long duration (Hakala, 2011; Laukkanen, et al., 2013).Other studies have noted that organizations that integrate and implement multiple strategic orientations are better able to achieve improved performance than following only one line of strategic behaviors (Beliaeva, et al., 2018; Krzakiewicz \& Cyfert, 2019).In this context, research studies have provided that MO yields superior performance, if it is simultaneously implemented with entrepreneurial orientation (EO) of a firm (Rodríguez-Gutiérrez, Moreno, \& Tejada, 2015). The joint effect of MO and EO produces a synergistic effect that facilitates organizations to satisfy the current needs of the consumers and aggressively pursue new market opportunities, and thus, it enables firms to achieve improved organizational performance (Amin, Thurasamy, Aldakhil, \& Kaswuri, 2016; Baker \& Sinkula, 2009). Building on firm's Resource-Based View (RBV), we argue that employing both MO and EO simultaneously, promotes greater performance and competitive advantage for SMEs.

This study contributes to the literature on strategy management and entrepreneurship in a number of ways and covers the limitations of the existing studies. Firstly, it empirically analyzes the effect of both the firm's MO and EO on organizational performance of SMEs by taking an integrated approach and responds to the recent call (Deutscher, Zapkau, Schwens, Baum, \& Kabst, 2016) for investigating the effects of multiple strategic orientations (such as MO \& EO) of the firms on organizational performance. Secondly, this is the first study of its nature that investigates the interaction effect of EO between the MO dimensions (customer-orientation, competitor-orientation and inter-functional coordination), and organizational performance. Thus, this work attempts to fill the gaps in the existing literature by addressing the future research calls (Buli, 2017; Deutscher, et al., 2016) for disintegrating the strategic orientations and examines the interplay between their sub dimensions and organizational performance. Thirdly, the few existing studies that have probed the combined effect of both MO and EO (Bhuian, Menguc, \& Bell, 2005; Li, Zhao, Tan, \& Liu, 2008; Yu, Nguyen, \& Chen, 2016) on organizational performance, have attempted to conceptualize the firm EO as three dimensional construct, namely: risktaking, innovativeness and pro-activeness, while this research conceptualizes EO as five dimension construct that includes risk-taking, innovativeness, pro-activeness, competitive-aggressiveness and autonomy dimensions, as proposed by Lumkpin and Dess (1996).

\section{Literature Review}

\subsection{MO-Disintegrated View}

MO has long been recognized as the application of marketing concepts and considered as an organizational resource that facilitates organizations to enhance their market performance (Spillan, Kara, King, \& McGinnis, 2013). The cultural perspective defines MO as "the organization culture that most effectively and efficiently creates the necessary behaviors for the creation of superior value for buyers and, thus, continuous superior performance for the business" Narver and Slater (1990, p. 21). Moreover, 
the cultural view point regards MO as three dimensions concept that comprises of customer-orientation, competitor-orientation and inter-functional coordination. The customer-orientation considers customer as the focal point of the organization (Deshpandé, Farley, \& Webster Jr, 1993; Pekovic, Rolland, \& Gatignon, 2016). A customer-oriented organization identifies and understands the wants and needs of the target consumers and responds them by creating value and fulfilling their needs. Considering customer-fist-approach can lead firms to increase customer satisfaction, customer retention and innovation, which further results in improved organizational performance (Kirca, et al., 2005).

Contrary to customer-orientation, competitor-orientation speaks of the inclination of a business towards apprehending the short-term advantages and disadvantages of the competitors in short-term as well as their strategies in the long term (Kevin Zheng Zhou, James R Brown, \& Chekitan S Dev, 2009a). This understanding improves the quality of services and products of organizations, and thus leads to retention of the existing customers. However, some studies argue that SMEs should not over emphasize on customers as it will result in over sighting the competitors' moves in the market, which may endanger the survival of the organization (O’Dwyer \& Gilmore, 2018).In the same line, other studies have noted that firms which are more inclined towards customers-orientation may overlook the changing needs of the customers and fail to bring more novelty in products (Frambach, Fiss, \& Ingenbleek, 2016). Thus, keeping a vigilant eye on strategic move of competitors facilitates a firm to plan and formulate strategies effectively (Chin, Lo, \& Ramayah, 2013) and deliver superior value to customers.

Inter-functional coordination component of MO refers to the inclination of an organization towards sharing the market related information among functional units to deliver higher value to clients (Narver and Slater, 1990, p. 21). It also reflects that all the useful capacities of a firm are on the same page and are positively contributing to the creation of superior customer value. SMEs, after collecting, filtering and processing, and sharing the market related data with the relevant people across the functional areas becomes able to devise marketing strategies, create value and satisfy needs of the customers (Gonzales, Vijande, \&Casielles, 2002; Tajeddini, 2011). Prior research has highlighted thatinformation sharing leads a firm towards innovation(Lonial \& Carter, 2015).Inter-functional coordination in the business culture can be managed bymany integration mechanisms including;face-to-face contacts, frequency of meetings, and sharedecisions (Tseng, Chang, \& Chen, 2019).

\subsection{Resource Based View}

Resource Based View (RBV)explains that a firm possesing unique resourceswould be able to attain competitive advantage and superior performance, compared to a firm that does not(Barney, 1991).Unique resources are those resources that are difficult for competitors to copy (Voola, Casimir, Carlson, \& Anushree Agnihotri, 2012), andinclude“all assets, capabilities, organizational processes, firm attributes, information, knowledge, etc. controlled by a firm that enables the firm to conceive of and implement strategies that improve its efficiency and effectiveness" (Barney,1991, p. 101).

$\mathrm{MO}$ and EO are the unique organizational resources that cannot be copied easily, as they are embedded in organizational culture. Research scholars have noted that effective implementation of organizational resources leads a firm to achieve greater performance and sustainable competitive advantage (Mac \& Evangelista, 2016).MO facilitates an organization to comprehend the customer-expressed needs, and results in providing relatively modified product to its customers, improving its process (Yadav, et al., 2019). EO helps firms in the renewal of existing practices, identification and the pursuit of new opportunities that result in achieving long-term organizational success (Lumpkin \& Dess, 1996; Noble, Sinha, \& Kumar, 2002; Presutti \& Odorici, 2019). Prior research has highlighted that deploying simultaneously the organizational resources,firms become able to achieve competitive advantage and improved performance (Clulow, Barry, \& Gerstman, 2007; Ferreira \& Fernandes, 2017).

This study builds upon theoretical insights from RBV and posits that entrepreneurial orientation, 
customer orientation, competitor orientation and inter-functional coordination are the capabilities and their unique configuration facilitates SMEs to achieve improved performance and long term success.

\subsection{MO Dimensions- Performance Relationship}

The preceding studies have accounted mixed findings over the direct relation of customer-orientation and firm performance (Thoumrungroje \& Racela, 2013; Noble, Sinha, \& Kumar, 2002). For example; Zhou et al. (2009) postulated that customer-orientation results in greater performance and competitive advantage in hotel industry. Chin, Lo, \& Ramayah (2013) reported no significant relationship of customer-orientation with organizational performance in star rated hotel in China. Babu (2018) reported that firm's customer-orientation has a positive association to customer-related performance in 435 companies operational in the service industries in the UK. In similar vein, a more recent study conducted by Neneh (2018) on 251 SMEs in South Africa concluded that customer-orientation has a significant positive influence on firm performance. Maurya, Mishra, Anand, \& Kumar (2015) noted that studies investigating the impact of customer-orientation on organizational performance in SME sector is scant in developing countries and emphasized the need for further investigation on the relationship between the aforementioned constructs to gain in-depth insights on the afore mentioned relationships.

The strategic management literature has debated the critical role of competitor orientation in enabling organizations to react effectively to the emerging customer needs, that ensures long term survival and increase profitability (Martin \& Grbac, 2003; Voola, et al., 2012). Chin, Lo and Ramayah (2013) conducted their study in 187 executive-level staff in three-star and beyond hotels in Malaysia and found that competitor orientation was significantly related to organizational performance. More recently, a study by O'Dwyer \& Gilmore (2018) concluded that competitor orientation benefits organizations to anticipate and surpass competitor activities and, results in defending and improving their market share.

Similarly, inter-functional coordination has been acknowledged as an important component of market orientation in marketing management and entrepreneurship literature. Similarly, Gaur, Vasudevan, \& Gaur (2011) found that inter-functional coordination is significantly and positively related to the organizational performance of manufacturing SMEs in India. In the same line, Asomaning \& Abdulai (2015) as well detected a substantial positive and significant relation between inter-functional coordination and market performance of small companies in Ghana. Prior research contends that interfunctional coordination nurtures a participative working environment that transforms the market related information into meaningful ideas across the organization and results in creativity, innovativeness and, competitive advantage (Ha, Lo, \& Ramaya, 2016). Based on the extant review of the existing literature, we suggest the following:

Hypothesis 1a (H1a): Customer orientation will have a significant positive effect on OP. Hypothesis $1 \mathrm{~b}(\mathrm{H} 1 \mathrm{~b})$ : Competitor orientation will have a significant positive effect on OP. Hypothesis 1c (H1c): Inter-functional coordination will have a significant positive effect on OP.

\subsection{The Moderating Role of EO}

EO refers to the inclination of an organization towards strategic decision making and behavioral action (Covin \& Lumpkin, 2011). The entrepreneurially-oriented organizations reflect proactiveness, innovativeness and risk-taking behavior characteristics in their strategic postures. These characteristics enable firms to identify and exploit new opportunities by their proactive and risk-taking behaviors and facilitate firms to achieve greater performance (Rauch et al., 2009). Prior research has highlighted that though MO and EO complement each other but they are separate constructs (Baker \& Sinkula, 2009). The integration of MO and EO results in customer satisfaction, new products performance and firm's profitability (Atuahene-Gima \& Ko, 2001; Kwak, Jaju, Puzakova, \& Rocereto, 2013). MO facilitates firms in devising strategic market planning through the generation of customer and competitor related information, whereas EO helps a firm in achieving growth related objectives by recognizing and taking advantage of the unexploited prospects in the market (Baker and Sinkula, 2009; Montiel-Campos, 
2018).MO provides a fertile environment where entrepreneurial posture is nurtured and results in firm's entrepreneurial actions (Mac \& Evangelista, 2016). Research scholars argue that firms over emphasizing on product innovation and overseeing the changing market needs, may face the challenges of survival and grow and, may further result in disappearance from the market (Thoumrungroje \& Racela, 2013).

There is handful of studies which have considered the interplay between EO and one or two dimensions of MO in direct relationship with OP. Less attention has been paid to the potential moderating role of EO on the MO dimensions and firm performance links. For example; Keskin (2006) reported that a firm with customer oriented approach is better able to generate market related knowledge that stimulates the entrepreneurial activities. Thoumrungroje and Racela (2013) postulated that aligning EO and customer orientation simultaneously results in innovation and new products development. The study conducted by Seilov (2015) in 138 small hospitality enterprises in Kazakhstan indicated that both customer and competitor orientations are in positive relation to EO. They provided that firms simultaneously deploying and implanting these three strategic postures are better able to cater to the changing needs of the market and achieve competitive advantage.

The strategy literature has highlighted that both competitor orientation and EO enable a firm to outperform its competitors through aggressive stance and leverage in the emerging market opportunities (Grinstein, 2008, Montiel-Campos, 2018). Ha, Lo \& Ramayah (2016) conducted their study in 180 SMEs in Malaysia. They concluded that competitor orientation has positive and significant influence on firm innovativeness and organizational performance. Prior researches argue that a competitor orientation helps firms generate information concerning the competitors' strategies in the market and facilitates firms to be proactive and take risk to exploit the emerging opportunities (Im \& Workman Jr, 2004; Wong \& Tong, 2012).

Similarly, Inter-functional coordination helps firms to bring employees on the same level of understanding and nurture a fertile environment for creativity, innovativeness and superior performance(Ha, Lo, \& Ramayah, 2016). More recently, Tseng, Chang, \& Chen (2019) conducted their study in 127 information technology firms in Taiwan and concluded that dissemination of information across the functional areas facilitates an organization to be more customers and competitors oriented; and update its technology, create superior value and effectively respond to the customers' changing needs.

This study disaggregates the MO construct into its fundamental components: customer-orientation, competitor-orientation and inter-functional coordination; hence, the following hypotheses are formed:

Hypothesis 2a (H2a): EO will significantly moderate the relationship between customer orientation and OP.

Hypothesis 2b (H2b): EO will significantly moderate the relationship between competitor orientation and OP.

Hypothesis 2c $(\mathrm{H} 2 \mathrm{c})$ : $\mathrm{EO}$ will significantly moderate the relationship between inter-functional coordination and OP.

\section{Research Methodology}

\subsection{Research Context}

The SME sector of Pakistan is the empirical context and population of the current study. Research on SMEs has attracted attention of the academics and practitioners across the world, given the stated potential benefits of the sector (Chikweche \& Bressan, 2018). The crucial role of SMEs has been acknowledged in many studies in promoting the social and economic development in the developing countries including Pakistan(Dar, Ahmed, \& Raziq, 2017). The crucial role of the SMEs in Pakistan can be reflected by the fact that the share of this sector in the overall businesses is $93 \%$ and has 
accommodated $80 \%$ of the non-agricultural labor force (Mirani \& Shah, 2012). However, SME sector contributes $30 \%$ to Gross Domestic Product (GDP) of the country. The factors that inhabit nurturing market and entrepreneurial oriented culture in the SMEs include lack of education and training of the owners/ and managers, inaccessibility to modern technology, lack of funds, and entrepreneurial skills (Soomro, Shah, \& Mangi, 2019; Yasir \& Majid, 2017). Though, the productivity of theSME sector is low compared to the large organizations, however, the role of this sector in improving the economic and social development, must not be overlooked. Recognizing the increasing importance of the SME sector, the current study seeks to scrutinize that how the owner/ and managers of SMEs can exploit the potential of this sector by integrating and configuring multiple strategic orientations like MO and EO simultaneously to achieve competitive advantage and improved performance.

\subsection{Sample Determination and Data Collection}

The sample of the study includes the SMEs in the city of Sialkot in Pakistan. We approached the official database of Chamber of Commerce \& Industry of Sialkot. We identified a total of 8000 firms, engaged in manufacturing operations, from the database (www.sialkotexport.com/ industry/Exporters_O.aspx) and identified 8000 firms. Using Krejcie and Morgan (1970), we distributed 367 questionnaires to the business heads, which included CEOs, senior executives and owners of the firms, since they are well informed persons due to their active involvement in the business operations. After making continuous follow-ups and telephonic calls, we could collect questionnaires from 239 firms. We dropped 26 firms due to incomplete information. We obtained 213 firms as our final sample size, making 58\% response rate.

Majority of the participating firms were from electronics appliances (50 percent), followed by Garments and apparels (47 percent), leather Goods (43 percent), Earthen Ware (26) silver ware (17 percent) and surgical goods (12 percent). Besides, majority of the firms had a small size with fewer than 100 employees (92 percent). Majority of the SMEs were male dominating, indicating $77.3 \%$ response rate. Majority of the participants had bachelor degree $(54.9 \%)$ followed by masters degree $(22.5 \%)$, intermediate $(18.8 \%)$, matriculation $(33.3 \%)$ and less $(0.5 \%)$.

\subsection{Measures}

The scales used for the constructs of the study were obtained from previous studies. The responses were taken on five-point Scale, where 5= strongly agree to $1=$ strongly disagree. We adapted a widely used MKTOR scale developed by Narver and Slater (1990) to measure the MO construct. Prior studies have noted that the MKTOR scale is operationally and conceptually more appealing (Blankson, et al., 2013; Hinson, Abdul-Hamid, \& Osabutey, 2017). The MKTOR scale has fifteen items in total, out of which4 items pertained to competitor orientation, 6 items to customer orientation and the remaining 5 items to competitor orientation. To confirm these dimensions, this study used second-order construct.

We conceptualized the EO construct with five dimensions based on Lumpkin and Dess (1996) and incorporated innovativeness, competitive aggressiveness, autonomy and risk-taking. We used EO using 17-items scale developed by Miller (1983), along with the items from Naman and Slevin (1993) and Covin and Slevin (1989) scales. We adapted 20 items scale of Hussain, Shah, Rehman, \& Khan (2018), for measuring the indicators of organizational performance (employee satisfaction, customer satisfaction, service quality, and growth) in subjective terms.

\subsection{Validity and Reliability}

Principal component analysis of MO items generated three components: customer-orientation, competitor-orientation and inter functional coordination, and explained 59 percent variance altogether in the items. The results indicated that the internal consistency of the scales for the three components was satisfactory, as Cronbach $\alpha$ values was reported to be 0.706 , 0.953and 0.860for the components respectively. 
Similarly the EO items generated one constituent and described $79 \%$ of the variance in the items. The scale was found to be suitable in terms of internal consistency with the Cronbach value of 0.899 . Organizational performance resulted in one constituent and described65\% of the variance in the items. Internal consistency of the scale was found suitable with the Cronbach $\alpha$ value of 0.926 .

\subsection{Data Analysis}

For testing our hypotheses with respect to MO dimensions of customer-orientation, competitororientation and inter-functional coordination with organizational performance relations, the Pearson correlation analysis, by means of SPSS version18.0 was employed. We performed linear regression analysis to ascertain the influence of MO dimensions of customer-orientation, competitor-orientation and inter-functional coordination on organizational performance. To evaluate the moderating effect of EO, hierarchical regression analysis by Baron and Kenny (1986)method of moderation was used to testify the hypotheses.

\section{Results}

\subsection{Descriptive Statistics}

Descriptive analysis, reported in Table 1, indicated that inter-functional coordination stood highest among the responses (mean=4.289, $\mathrm{SD}=.543$ ), followed by customer orientation (mean=4.087, $\mathrm{SD}=.673$ ) and competitor orientation (mean=3.359, $\mathrm{SD}=.805$ ). The results further reveal that, SMEs operating in Pakistan, acknowledge the collecting and dissemination of market information across the organization, a source of competitive advantage by offering superior value to clients and outperforming the competitors. The findings of the current study support the previous studies (Mac \& Evangelista, 2016; Zhou, et al., 2009a)highlighting that a market orientated firm reflects the characteristics of (a) customer orientation - considering client as the focal-point of the business (b) competitor orientation beating the competitors by providing superior value, and (c) inter-functional coordination - information sharing and utilization to adapt to the external environment, thereby, ensuring survival and achieving long-term growth.

\subsection{Correlation Analysis}

Table 1 below presents the results of the correlation analysis among variables of the study. Using Pearson correlation method, results indicate that organizational performance has positive and significant association to MO dimensions of customer-orientation $(\mathrm{r}=0.543, \mathrm{p}<0.01)$, competitororientation $(r=0.649, \mathrm{p}<0.01)$, and for inter-functional coordination $(\mathrm{r}=.401, \mathrm{p}<0.01)$. We used the Variance Inflation Factor (VIF) test to examine the issue of multicollinearity before the regression models were run. The values were found to be less than 10, hence, no issue of multicollinearity was found and the data was processed for further analysis.

Table 1: Correlation Analysis of MO Dimensions, EO and OP

\begin{tabular}{lllllllll}
\hline No. & Variables & Mean & SD & $\mathbf{1}$ & $\mathbf{2}$ & $\mathbf{3}$ & $\mathbf{4}$ & $\mathbf{5}$ \\
\hline 1 & Entrepreneurial Orientation & 3.632 & 0.549 & 1 & & & & \\
2 & Customer Orientation & 4.086 & 0.673 & 0.285 & 1 & & & \\
3 & Competitor Orientation & 3.359 & 0.805 & 0.733 & -0.068 & 1 & & \\
4 & & & & & & \\
5 & IF coordination & 4.289 & 0.543 & 0.154 & 0.398 & -0.067 & 1 & \\
\hline
\end{tabular}

Note: $\mathrm{P}<0.01$ level (2 tailed).

\subsection{Hypotheses Testing}

Table 2 presents the statistical results of the main hypothesis of the study. Results of regression analysis showed that customer-orientation $(\beta=.449, \mathrm{t}=12.379, \mathrm{p}=.000)$, competitor-orientation $(\beta=.314, t=$ 9.394, $p=.000)$, and inter-functional coordination $(\beta=.343, t=6.354, p=.000)$ significantly and positively affect firm's performance. Results of the regression analysis on the direct effects of MO dimensions on organizational performance provide support to main hypothesis $H 1 a, H 1 b$, and $H 1 c$ of the study. The results further indicated that the impact on the organizational performance for customer 
orientation $(\beta=.449)$ is higher than the inter-functional coordination $(\beta=.343)$ and competitor orientation $(\beta=.314)$ dimensions of MO.

Table 2: Model Coefficients and Summary for the Constructs

\begin{tabular}{|c|c|c|c|c|c|c|c|c|}
\hline & $\mathbf{R}$ & $\mathbf{R 2}$ & Adj. R2 & $\mathbf{F}$ & Sig & Beta & t-value & Sig. \\
\hline \\
\hline \multicolumn{9}{|c|}{ Dependant variable: organizational performance } \\
\hline Customer & 0.649 & 0.421 & 0.418 & 153.248 & 0.000 & & & \\
\hline \multicolumn{9}{|l|}{ Orientation } \\
\hline \multirow{3}{*}{$\begin{array}{l}\text { Entrepreneurial } \\
\text { Orientation }\end{array}$} & & & & & & 0.449 & 12.379 & 0.000 \\
\hline & 0.761 & 0.579 & 0.577 & 289.687 & 0.000 & & & \\
\hline & & & & & & 0.645 & 17.020 & 0.000 \\
\hline \multirow[t]{2}{*}{ CustO*EO } & 0.880 & 0.774 & 0.773 & 724.515 & 0.000 & & & \\
\hline & & & & & & 0.110 & 26.917 & 0.000 \\
\hline \\
\hline Competitor & 0.543 & 0.294 & 0.291 & 88.064 & 0.000 & & & \\
\hline \\
\hline \multirow[t]{2}{*}{ CompO*EO } & 0.666 & 0.444 & 0.441 & 168.344 & 0.000 & 0.314 & & 0.000 \\
\hline & & & & & & 0.070 & 12.975 & 0.000 \\
\hline \multirow{3}{*}{$\begin{array}{l}\text { Model } 3 \\
\text { Inter-functional } \\
\text { Coordination }\end{array}$} & & & & & & & & \\
\hline & 0.401 & 0.161 & 0.157 & 40.373 & 0.000 & & & \\
\hline & & & & & & 0.343 & 6.354 & 0.000 \\
\hline \multirow[t]{2}{*}{ IFC*EO } & 0.790 & 0.625 & 0.623 & 351.226 & 0.000 & & & \\
\hline & & & & & & 0.112 & 18.741 & 0.000 \\
\hline
\end{tabular}

The EO's moderating impact was tested using Baron and Kenny (1986). The moderation analysis' results (Step 1) indicated that customer-orientation $\left(\mathrm{R}^{2}=.421\right)$ has positive and significant influence on $\mathrm{OP}$ as indicated by their respective beta coefficients and significance values, causing variation of $42.1 \%$ in organizational performance. The results further show that when EO is included as a moderator (Step 2) between customer-orientation and organization performance relationship, the product of customerorientation and EO resulted in a variation of $77.4 \%\left(\mathrm{R}^{2}=0.774\right)$ in OP, which implies that the effect is higher than the effect of taking customer-orientation as independent variable in isolation.

Similarly, competitor orientation $\left(\mathrm{R}^{2}=.294\right)$ and inter-functional coordination $\left(\mathrm{R}^{2}=.161\right)$ are causing a variation of $29.4 \%$ and $6.1 \%$ in the organizational performance. The $\mathrm{R}^{2}$ values for the product of CompO*EO (0.294) and product of IFC*EO (0.625) indicated that when EO acts as moderator, the variations caused by both the dimensions is higher than the variation caused by these two dimensions, if taken as independent variables alone. Significance of beta coefficient of the products confirms that EO significantly and positively affects the relation between MO dimensions and OP. Thus, the results receive empirical support to confirm the hypotheses $H 2 d, H 2 e$, and $H 2 f$ of the study.

\section{Discussion and Conclusion}

This study was aimed to investigate the moderating effect of EO on the relationships between MO dimensions and OP. The results of regression analysis on customer-orientation support the previous studies indicating that customer-orientation has a significant and positive influence on firm performance (Neneh, 2018; Kevin Zheng Zhou, James R Brown, \& Chekitan S Dev, 2009b).The results reveal that SMEs in Pakistan are over emphasizing the customer wants and needs. However, prior research has highlighted that firms which over emphasize on fulfilling the current needs of the customer may fail to bring novelty in products and developing innovations (Frambach, et al., 2016). 
The regression result on competitor orientation supports the previous studies indicating that competitor orientation has crucial role in improving the organizational performance. Competitor oriented firms are better able to generate market information related to competitors and create superior value for customers (Chin, Lo, \& Ramayah, 2013; Jaffari, Salman, \& Abideen, 2011), and outperform the competitors in the market. The result on inter-functional coordination provides support to the previous studies (Ha, Lo, \& Ramaya, 2016; Gaur, et al., 2011) highlighting that inter-functional coordination facilitates the continuous inflow of the market information and results in well-timed identification and satisfaction of customer needs, outperforming the competitors and achieving the competitive advantage.

The study as well investigated the moderating role of EO on the MO dimensions and organizational performance relationships. The results indicated that EO positively affects the relationship between customer-orientation and organizational performance and supports the prior research (Seilov, 2015; Thoumrungroje \& Racela, 2013) that found that customer-orientation spurs EO of a firm, resulting in competitive benefit and improved functioning. Customer-orientation facilitates EO, in that, it helps firms to learn what the customers want, while EO enables firms, based on learning from market, to exploit new business opportunities and launch new products and services (Keskin, 2006; Smith \& Jambulingam, 2018).

The current study's results also support that EO significantly and positively moderates the competitor orientation and organizational performance relationship. The findings support the existing studies indicating that implementation of both competitor orientation and EO simultaneously enable firms to outperform its competitors through aggressive stance and exploit the emerging opportunities in the market(Grinstein, 2008; Montiel-Campos, 2018).

The results of this study further indicate that EO significantly and positively moderates the relationship between inter-functional coordination and organizational performance relationship. The results of the study are consistent with the findings of the previous studies (Ha, et al., 2016; Tajeddini, Trueman, \& Larsen, 2006) indicating that generating and sharing information across the organization results in innovativeness, creativity and improved firm performance. This study suggest that SMEs in developing economies like Pakistan must deploy multiple orientations like MO and EO, as it would make them to be in better position in creating superior customer value and identifying and, exploiting the market opportunities. This would also facilitate them to achieve long-term growth and success.

\section{Limitations and Future Research Opportunities}

This study, like many other endeavors on strategic orientation, holds some limitations that may be addressed by the future studies. First, this research has mainly focused on manufacturing SMEs, operating in the emerging economy of Pakistan. Thus, we recommend that future research should test the model of the study in other emerging economies to gain more in-depth insights on the interplay between strategic orientations and their influence on organizational performance. Second, the data was collected from the SMEs operating in the Sialkot city of Punjab, Pakistan; therefore, we suggest that future research sought to collect data from other cities of the country like Peshawar, Islamabad and Karachi in order to overcome the limitations of this study. Third, this study used subjective indicators to measures organizational performance of SMEs. Scholars are encouraged to take objective indicators of performance such as returns on investment, profitability and returns on assets in order to get better insights on the interplay between strategic orientation and OP. Fourth, this study disintegrated MO into its underlying dimensions. Future studies are advised to decompose the EO construct and investigate the moderating effects of the sub dimensions on the direct effects of MO dimensions and OP in order to enrich the understanding of the readers on the interplay between the decomposed constructs and OP.

Fifth, the sample unit of this study comprised manufacturing SMEs. The existing studies examining the strategic orientation -organizational performance relationships are scant in service sector of Pakistan. 
Using the model of this study, future research is suggested to be carried out in the service sector in general and hospitality industry in particular. Finally, current study is cross-sectional survey design and considers the presence of the relationships between the study variables at a set point in time. Future research, using longitudinal study design, is encouraged to be conducted in order to provide in-depth insights into how the relationships between the study variables evolve over time.

\section{References}

Alnawas, I., \& Hemsley-Brown, J. (2019). Market orientation and hotel performance: investigating the role of high-order marketing capabilities. International Journal of Contemporary Hospitality Management, 31(4), 1885-1905.

Amin, M., Thurasamy, R., Aldakhil, A. M., \& Kaswuri, A. H. B. (2016). The effect of market orientation as a mediating variable in the relationship between entrepreneurial orientation and SMEs performance. Nankai Business Review International, 7(1), 39-59.

Asomaning, R., \& Abdulai, A. (2015). An empirical evidence of the market orientation-market performance relationship in Ghanaian small businesses. Educational Research International, $4(2), 69-86$.

Atuahene-Gima, K., \& Ko, A. (2001). An empirical investigation of the effect of market orientation and entrepreneurship orientation alignment on product innovation. Organization science, 12(1), 5474.

Baker, W. E., \& Sinkula, J. M. (1999). The synergistic effect of market orientation and learning orientation on organizational performance. Journal of the academy of Marketing Science, 27(4), 411-427.

Baker, W. E., \& Sinkula, J. M. (2009). The Complementary Effects of Market Orientation and Entrepreneurial Orientation on Profitability in Small Businesses*. Journal of Small Business Management, 47(4), 443-464.

Baron, R. M., \& Kenny, D. A. (1986). The moderator-mediator variable distinction in social psychological research: Conceptual, strategic, and statistical considerations. Journal of personality and social psychology, 51(6), 1173-1182.

Beliaeva, T., Shirokova, G., Wales, W., \& Gafforova, E. (2018). Benefiting from economic crisis? Strategic orientation effects, trade-offs, and configurations with resource availability on SME performance. International Entrepreneurship and Management Journal, 1-30.

Beneke, J., Blampied, S., Dewar, N., Soriano, L., \& Deacon, J. (2016). The impact of market orientation and learning orientation on organisational performance: a study of small to medium sized enterprises in Cape Town, South Africa. Journal of Research in Marketing and Entrepreneurship, 18(1), 90-108.

Bhuian, S. N., Menguc, B., \& Bell, S. J. (2005). Just entrepreneurial enough: the moderating effect of entrepreneurship on the relationship between market orientation and performance. Journal of Business Research, 58(1), 9-17.

Blankson, C., Cowan, K., Crawford, J., Kalafatis, S., Singh, J., \& Coffie, S. (2013). A review of the relationships and impact of market orientation and market positioning on organisational performance. Journal of Strategic Marketing, 21(6), 499-512.

Buli, B. M. (2017). Entrepreneurial orientation, market orientation and performance of SMEs in the manufacturing industry: Evidence from Ethiopian enterprises. Management Research Review, 40(3), 292-309.

Chikweche, T., \& Bressan, A. (2018). A systematic review of future research challenges and prospects of organizational learning research in small medium size enterprises. Journal of Small Business \& Entrepreneurship, 30(2), 175-191.

Chin, C.-H., Lo, M.-C., \& Ramayah, T. (2013). Market orientation and organizational performance: The moderating role of service quality. SAGE Open, 3(4), 1-14.

Clulow, V., Barry, C., \& Gerstman, J. (2007). The resource-based view and value: the customer-based view of the firm. Journal of European industrial training, 31(1), 19-35. 
Covin, J. G., \& Lumpkin, G. T. (2011). Entrepreneurial orientation theory and research: Reflections on a needed construct. Entrepreneurship Theory and Practice, 35(5), 855-872.

Covin, J. G., \& Slevin, D. P. (1989). Strategic management of small firms in hostile and benign environments. Strategic Management Journal, 10(1), 75-87.

Dar, M. S., Ahmed, S., \& Raziq, A. (2017). Small and medium-size enterprises in Pakistan: Definition and critical issues. Pakistan Business Review, 19(1), 46-70.

Deshpandé, R., Farley, J. U., \& Webster Jr, F. E. (1993). Corporate culture, customer orientation, and innovativeness in Japanese firms: a quadrad analysis. The Journal of Marketing, 23-37.

Deutscher, F., Zapkau, F. B., Schwens, C., Baum, M., \& Kabst, R. (2016). Strategic orientations and performance: A configurational perspective. Journal of Business Research, 69(2), 849-861.

Ferreira, J., \& Fernandes, C. (2017). Resources and capabilities' effects on firm performance: what are they? Journal of Knowledge Management, 21(5), 1202-1217.

Frambach, R. T., Fiss, P. C., \& Ingenbleek, P. T. (2016). How important is customer orientation for firm performance? A fuzzy set analysis of orientations, strategies, and environments. Journal of Business Research, 69(4), 1428-1436.

Gaur, S. S., Vasudevan, H., \& Gaur, A. S. (2011). Market orientation and manufacturing performance of Indian SMEs: Moderating role of firm resources and environmental factors. European Journal of Marketing, 45(7/8), 1172-1193.

Grewal, R., \& Tansuhaj, P. (2001). Building organizational capabilities for managing economic crisis: The role of market orientation and strategic flexibility. Journal of Marketing, 65(2), 67-80.

Grinstein, A. (2008). The relationships between market orientation and alternative strategic orientations: a meta-analysis. European Journal of Marketing, 42(1/2), 115-134.

Ha, S. T., Lo, M. C., \& Ramayah, T. (2016). Decomposing market orientation and its relationship to innovativeness of SMEs in Malaysia: the moderating effects of market turbulence. Journal for International Business and Entrepreneurship Development, 9(3), 273-290.

Hakala, H. (2011). Strategic orientations in management literature: three approaches to understanding the interaction between market, technology, entrepreneurial and learning orientations. International Journal of Management Reviews, 13(2), 199-217.

Hinson, R. E., Abdul-Hamid, I. K., \& Osabutey, E. L. (2017). Investigating market orientation and positioning in star-rated hotels in Ghana. International Journal of Contemporary Hospitality Management, 29(10), 2629-2646.

Hussain, J., Shah, F. A., Rehman, W., \& Khan, Y. (2018). Learning orientation and performance: the interaction effect of entrepreneurial orientation Pakistan Business Review, 19(4), 960-977.

Im, S., \& Workman Jr, J. P. (2004). Market orientation, creativity, and new product performance in high-technology firms. Journal of Marketing, 114-132.

Jaffari, I., Salman, S., \& Abideen, U. (2011). Few determinants of product and firm performance: A case of FMCG industry. European Journal of Social Sciences, 19(4), 561-572.

Keskin, H. (2006). Market orientation, learning orientation, and innovation capabilities in SMEs: An extended model. European Journal of Innovation Management, 9(4), 396-417.

Kirca, A. H., Jayachandran, S., \& Bearden, W. O. (2005). Market orientation: a meta-analytic review and assessment of its antecedents and impact on performance. Journal of Marketing, 24-41.

Krejcie, R. V., \& Morgan, D. W. (1970). Determining sample size for research activities. Educational and Psychological Measurement, 30, 607-610.

Krzakiewicz, K., \& Cyfert, S. (2019). Strategic orientations of the organization-entrepreneurial, market and organizational learning. Management, 23(1), 7-19.

Kwak, H., Jaju, A., Puzakova, M., \& Rocereto, J. F. (2013). The Connubial Relationship Between Market Orientation and Entrepreneurial Orientation. The Journal of Marketing Theory and Practice, 21(2), 141-162.

Laukkanen, T., Nagy, G., Hirvonen, S., Reijonen, H., \& Pasanen, M. (2013). The effect of strategic orientations on business performance in SMEs: A multigroup analysis comparing Hungary and Finland. International Marketing Review, 30(6), 510-535. 
Li, Y., Zhao, Y., Tan, J., \& Liu, Y. (2008). Moderating Effects of Entrepreneurial Orientation on Market Orientation-Performance Linkage: Evidence from Chinese Small Firms*. Journal of Small Business Management, 46(1), 113-133.

Lonial, S. C., \& Carter, R. E. (2015). The Impact of Organizational Orientations on Medium and Small Firm Performance: A Resource Based Perspective. Journal of Small Business Management, 53(1), 94-113.

Lumpkin, G. T., \& Dess, G. G. (1996). Clarifying the entrepreneurial orientation construct and linking it to performance. Academy of Management Review, 21(1), 135-172.

Mac, L., \& Evangelista, F. (2016). The relative impact of market orientation and entrepreneurship on export performance: do we really know enough? Journal of Global Marketing, 29(5), 266-281.

Martin, J. H., \& Grbac, B. (2003). Using supply chain management to leverage a firm's market orientation. Industrial marketing management, 32(1), 25-38.

Maurya, U. K., Mishra, P., Anand, S., \& Kumar, N. (2015). Corporate identity, customer orientation and performance of SMEs: Exploring the linkages. IIMB Management Review, 27(3), 159-174.

Miller, D. (1983). The correlates of entrepreneurship in three types of firms. Management science, 29(7), 770-791.

Mirani, M. A., \& Shah, S. M. M. (2012). What does it take to succeed in small business in Pakistan? the Lessons for Emerging Entrepreneurs. International Journal of Trade, Economics and Finance, 3, 167-169.

Mohiuddin Babu, M. (2018). Impact of firm's customer orientation on performance: the moderating role of interfunctional coordination and employee commitment. Journal of Strategic Marketing, 26(8), 702-722.

Montiel-Campos, H. (2018). Entrepreneurial orientation and market orientation: systematic literature review and future research. Journal of Research in Marketing and Entrepreneurship, 20(2), 292322.

Naman, J. L., \& Slevin, D. P. (1993). Entrepreneurship and the concept of fit: A model and empirical tests. Strategic Management Journal, 14(2), 137-153.

Narver, J. C., \& Slater, S. F. (1990). The effect of a market orientation on business profitability. The Journal of Marketing, 20-35.

Neneh, B. N. (2018). Customer orientation and SME performance: the role of networking ties. African Journal of Economic and Management Studies, 9(2), 178-196.

Noble, C. H., Sinha, R. K., \& Kumar, A. (2002). Market orientation and alternative strategic orientations: a longitudinal assessment of performance implications. The Journal of Marketing, 25-39.

O’Dwyer, M., \& Gilmore, A. (2018). Competitor orientation in successful SMEs: An exploration of the impact on innovation. Journal of Strategic Marketing, 27(1), 21-37.

Pekovic, S., Rolland, S., \& Gatignon, H. (2016). Customer orientation and organizational innovation: the case of environmental management practices. Journal of Business \& Industrial Marketing, 31(7), 835-848.

Presutti, M., \& Odorici, V. (2019). Linking entrepreneurial and market orientation to the SME's performance growth: the moderating role of entrepreneurial experience and networks. International Entrepreneurship and Management Journal, 15(3), 697-720.

$\mathrm{Qu}$, R. (2014). Market orientation and organizational performance linkage in Chinese hotels: The mediating roles of corporate social responsibility and customer satisfaction. Asia Pacific Journal of Tourism Research, 19(12), 1399-1416.

Rodríguez-Gutiérrez, M. J., Moreno, P., \& Tejada, P. (2015). Entrepreneurial orientation and performance of SMEs in the services industry. Journal of Organizational Change Management, 28(2), 194-212.

Seilov, G. A. (2015). Does the adoption of customer and competitor orientations make small hospitality businesses more entrepreneurial? Evidence from Kazakhstan. International Journal of Contemporary Hospitality Management, 27(1), 71-86. 
Shah, S. M. A., El-Gohary, H., \& Hussain, J. G. (2015). An investigation of market orientation (Mo) and tourism Small and Medium-Sized Enterprises'(SMEs) performance in developing countries: a review of the literature. Journal of travel \& tourism marketing, 32(8), 990-1022.

Smith, B., \& Jambulingam, T. (2018). Entrepreneurial orientation: Its importance and performance as a driver of customer orientation and company effectiveness among retail pharmacies. International Journal of Pharmaceutical and Healthcare Marketing, 12(2), 158-180.

Soomro, B. A., Shah, N., \& Mangi, S. (2019). Factors affecting the entrepreneurial leadership in smalland medium-sized enterprises (SMEs) of Pakistan: An empirical evidence. World Journal of Entrepreneurship, Management and Sustainable Development, 15(1), 31-44.

Spillan, J. E., Kara, A., King, D. O., \& McGinnis, M. A. (2013). Market orientation and firm performance: An empirical analysis of Ghanaian microenterprises. Journal of Global Marketing, 26(5), 258-272.

Tajeddini, K. (2011). Customer orientation, learning orientation, and new service development: an empirical investigation of the Swiss hotel industry. Journal of Hospitality \& Tourism Research, 35(4), 437-468.

Tajeddini, K., Trueman, M., \& Larsen, G. (2006). Examining the effect of market orientation on innovativeness. Journal of Marketing Management, 22(5-6), 529-551.

Theodoridis, P. K., \& Panigyrakis, G. G. (2011). Internal marketing, market orientation and organisational performance: the mythological triangle in a retail context. European Retail Research, 24(02), 33-67.

Thoumrungroje, A., \& Racela, O. (2013). The contingent role of customer orientation and entrepreneurial orientation on product innovation and performance. Journal of Strategic Marketing, 21(2), 140-159.

Tseng, C.-H., Chang, K.-H., \& Chen, H.-W. (2019). Strategic Orientation, Environmental Innovation Capability, and Environmental Sustainability Performance: The Case of Taiwanese Suppliers. Sustainability, 11(4), 1127.

Voola, R., Casimir, G., Carlson, J., \& Anushree Agnihotri, M. (2012). The effects of market orientation, technological opportunism, and e-business adoption on performance: A moderated mediation analysis. Australasian Marketing Journal (AMJ), 20(2), 136-146.

Wong, S. K. S., \& Tong, C. (2012). The influence of market orientation on new product success. European Journal of Innovation Management, 15(1), 99-121.

Yadav, S. K., Tripathi, V., \& Goel, G. (2019). Mediating effect of innovation with market orientation and performance relationship. Management Research, 17(2), 152-167.

Yasir, M., \& Majid, A. (2017). Impact of knowledge management enablers on knowledge sharing: is trust a missing link in SMEs of emerging economies? World Journal of Entrepreneurship, Management and Sustainable Development, 13(1), 16-33.

Yu, X., Nguyen, B., \& Chen, Y. (2016). Internet of things capability and alliance: Entrepreneurial orientation, market orientation and product and process innovation. Internet Research, 26(2), 402-434.

Zhou, K. Z., Brown, J. R., \& Dev, C. S. (2009a). Market orientation, competitive advantage, and performance: a demand-based perspective. Journal of Business Research, 62, 1063-1070.

Zhou, K. Z., Brown, J. R., \& Dev, C. S. (2009b). Market orientation, competitive advantage, and performance: A demand-based perspective. Journal of Business Research, 62(11), 1063-1070. 
